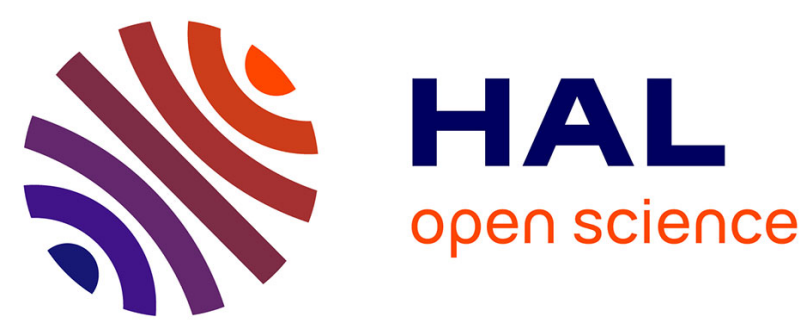

\title{
Assessing ecotoxicity and uptake of metals and metalloids in relation to two different earthworm species (Eiseina hortensis and Lumbricus terrestris)
}

Thibaut Leveque, Yvan Capowiez, Eva Schreck, Christophe Mazzia, Melanie Auffan, Yann Foucault, Annabelle Austruy, Camille Dumat

\section{To cite this version:}

Thibaut Leveque, Yvan Capowiez, Eva Schreck, Christophe Mazzia, Melanie Auffan, et al.. Assessing ecotoxicity and uptake of metals and metalloids in relation to two different earthworm species (Eiseina hortensis and Lumbricus terrestris). Environmental Pollution, 2013, 179, pp.232241. 10.1016/j.envpol.2013.03.066 . hal-01326829

\section{HAL Id: hal-01326829 \\ https://hal.science/hal-01326829}

Submitted on 29 May 2020

HAL is a multi-disciplinary open access archive for the deposit and dissemination of scientific research documents, whether they are published or not. The documents may come from teaching and research institutions in France or abroad, or from public or private research centers.
L'archive ouverte pluridisciplinaire HAL, est destinée au dépôt et à la diffusion de documents scientifiques de niveau recherche, publiés ou non, émanant des établissements d'enseignement et de recherche français ou étrangers, des laboratoires publics ou privés. 


\title{
Assessing ecotoxicity and uptake of metals and metalloids in relation to two different earthworm species (Eiseina hortensis and Lumbricus terrestris)
}

\author{
Thibaut Leveque ${ }^{\mathrm{a}, \mathrm{b}}$, Yvan Capowiez ${ }^{\mathrm{c}}$, Eva Schreck $^{\mathrm{d}}$, Christophe Mazzia ${ }^{\mathrm{e}}$, Mélanie Auffan ${ }^{\mathrm{f}}$, \\ Yann Foucault ${ }^{a, b, g}$, Annabelle Austruy ${ }^{a, b}$, Camille Dumat ${ }^{a, b, *}$
}

${ }^{a}$ Université de Toulouse, INP-ENSAT, Av. Agrobiopôle, PO Box 107, Auzeville-Tolosane, 31326 Castanet-Tolosan, France

${ }^{\mathrm{b}}$ UMR 5245 CNRS-INP-UPS, EcoLab, Av. Agrobiopôle, PO Box 107, Auzeville-Tolosane, 31326 Castanet-Tolosan, France

${ }^{\mathrm{c}}$ INRA, UR 1115, Plantes et Systèmes Horticoles, Site Agroparc, 84914 Avignon cedex 09, France

${ }^{\mathrm{d}}$ GET, UMR 5563 CNRS/UPS/IRD/CNES, 14 Avenue Edouard Belin, 31400 Toulouse, France

e IMBE, UMR CNRS 7263 - IRD 237, France

${ }^{\mathrm{f}}$ CEREGE, Europôle Méditerranéen de l'Arbois, Avenue Louis Philibert, BP 80, 13545 Aix en Provence cedex 04, France

${ }^{\mathrm{g}}$ STCM, 30 Avenue Fondeyre, 31200 Toulouse, France

Keywords:

Earthworms

Inorganic trace element

Ecotoxicity

Cast production

Soil properties

\begin{abstract}
A B S T R A C T
Due to diffuse atmospheric fallouts of process particles enriched by metals and metalloids, polluted soils concern large areas at the global scale. Useful tools to assess ecotoxicity induced by these polluted soils are therefore needed. Earthworms are currently used as biotest, however the influence of specie and earthworm behaviour, soil characteristics are poorly highlighted. Our aim was therefore to assess the toxicity of various polluted soils with process particles enriches by metals and metalloids $(\mathrm{Pb}, \mathrm{Cd}, \mathrm{Cu}, \mathrm{Zn}$, As and $\mathrm{Sb}$ ) collected from a lead recycling facility on two earthworm species belonging to different ecological types and thus likely to have contrasted behavioural responses (Eiseina hortensis and Lumbricus terrestris).

The combination of behavioural factors measurements (cast production and biomass) and physicochemical parameters such as metal absorption, bioaccumulation by earthworms and their localization in invertebrate tissues provided a valuable indication of pollutant bioavailability and ecotoxicity. Soil characteristics influenced ecotoxicity and metal uptake by earthworms, as well as their soil bioturbation.
\end{abstract}

\section{Introduction}

In the last decade, the soil area polluted by atmospheric fine particles enriched with metals and metalloids (noticed PM) has increased (Schreck et al., 2011), especially due to the development of metal recycling activities (Foucault et al., 2013; Uzu et al., 2009). As reported by Cecchi et al. (2008), the different stages in the recycling process in these facilities lead to PM emissions which contaminate the soil and therefore have a potential impact on terrestrial ecosystems (Schreck et al., 2011). Earthworms are the dominant soil organisms in most temperate and tropical grassland soils (Lee, 1985). As reported by Nahmani et al. (2007a) they modify chemical and physical soil parameters, mix leaf litter with the soil, form and stabilize aggregates and generate soil porosity. According to Ruiz et al. (2011), they can also influence the behaviour of inorganic elements

\footnotetext{
* Corresponding author.

E-mail address: camille.dumat@ensat.fr (C. Dumat).
}

in soils (pollutants and nutrients). Earthworms are therefore important terrestrial model organisms for toxicity testing to assess environmental pollution (Schreck et al., 2008; Capowiez et al., 2010; Schreck et al., 2012). These soil organisms can provide important information about environmental risks and could serve as useful biological indicators of contamination because of the fairly consistent correlation between the concentration of some contaminants in their tissues and in soils (Nannoni et al., 2011). Pauget et al. (2011) concluded that only partial information is obtained from the chemical extractions currently used to assess metal bioavailability: biota measures are therefore needed for risk assessment studies.

In their review about the interactions between earthworms and inorganic trace element (ITE), Nahmani et al. (2007b) considered several parameters such as earthworm species, soil type, metal type and experimental conditions. They suggested several priority areas for further studies: in particular, other earthworm species besides Eisenia fetida (currently used in normalized ecotoxicity tests) should be studied in order to apply the large existing database on this 
earthworm to other soil dwelling species. Then, so that studies from different research experiments can be accurately compared, a set of standard protocols for the exposure and depuration periods is needed and precise parameters, such as soil chemical and physical properties, should be defined. It was also recommended that more field or terrestrial model studies using real contaminated soils rather than metal-amended artificial soils should be performed. Recently Schreck et al. (2011) showed that ageing can influence metal transfer and ecotoxicity. Furthermore, although ITE bioaccumulation by earthworms has been widely studied for one ITE in particular (Nahmani et al., 2007b) and with spiked soils (Nahmani et al., 2007a,b), studies on multi-metal pollution under field or close to real conditions remain not numerous (Andre et al., 2010a, 2010b; Nannoni et al., 2011). It is increasingly accepted that for risk assessments, measures of total ITE concentrations must be complemented with data on the available or mobile ITE concentrations in soils. Therefore numerous studies reported the use of chemical extractions such as $\mathrm{CaCl}_{2}$ extraction to assess metal bioavailability (Uzu et al., 2009; Schreck et al., 2011). Actually, these chemical extractions can break bonds between metals and clay or organic matter, releasing metals and making them bioavailable for earthworms (Owojori et al., 2009). Moreover, few soluble and unfixed to organic matter particles are then available for earthworms via soil ingestion.

According to Morgan and Morgan (1999), earthworm behaviour such as burrowing and feeding affect their exposure to the pollutants. Parameters such as the earthworm species and soil conditions could therefore strongly influence metal ecotoxicity (Tomlin, 1992). In addition, as mentioned by Capowiez et al. (2010), there is currently a lack of ecotoxicity tests adapted to ecologically relevant earthworm species and with endpoints which could be directly related to their ecological role in the soil. A new behavioural biomarker, cast production, was thus recently proposed by Capowiez et al. (2010). This test was first elaborated for Lumbricus terrestris (high bioturbation activity) under laboratory conditions, but was then adapted to Aporrectodea caliginosa (Dittbrenner et al., 2011). Once deposited on the soil surface, PM can have deleterious effects on soil micro and macrofauna. Earthworm soil activities such as burrowing, casting and mixing of litter and soil (bioturbation) have important consequences for soil processes and properties. Thus earthworms may also modify PM fate, mobility (Sizmur and Hodson, 2009), availability (Ruiz et al., 2011) and speciation. However, those modifications will be less pronounced if PM toxicity affects earthworm behaviour (Vorenhout et al., 2000). It is therefore important to first assess any behavioural changes in earthworms which may be induced by PM.

The aim of the present study was to assess the toxicity of various polluted soils on two earthworm species (Eiseina hortensis and Lumbricus terrestris). The soils were collected from a lead recycling facility and contaminated with $\mathrm{Pb}, \mathrm{Cd}, \mathrm{Cu}, \mathrm{Zn}$, As and $\mathrm{Sb}$. The two earthworm species belong to two different ecological types and are thus likely to have contrasting behavioural responses. The original and innovative aspect of this paper consists in the utilization of historically polluted soil from a lead recycling facility. In this way, a cocktail of metals and metalloids, as well as the influence of different soil characteristics, could be studied, to carry out complementary ecotoxicity tests. Then, metal bioaccumulation studies and microscopy experiments will be performed to better understand metal localization and tissues storage in earthworms in order to investigate the uptake pathway.

\section{Materials and methods}

\subsection{Soil preparation}

The heavily polluted soil (noted as S1) used in this study was collected from a lead recycling facility at a chemical metal treatment company (STCM) which currently recycles batteries. The facility is located in the urban area of Toulouse, in the southwest of France $\left(43^{\circ} 38^{\prime} 12^{\prime \prime} \mathrm{N}, 01^{\circ} 25^{\prime} 34^{\prime \prime} \mathrm{E}\right)$. For several decades, the industrial activities at the site have produced high concentrations of $\mathrm{Pb}$ and other ITE such as Cd, Cu, As, Sb, Zn in surface soils (Uzu et al., 2009; Schreck et al., 2011). This historically polluted soil (from the facility courtyard) was sampled from the top 0$25 \mathrm{~cm}$ soil layer, air-dried at ambient temperature for a week, disaggregated and, finally, sieved to retain aggregates smaller than $2 \mathrm{~mm}$. Total ITE concentrations were measured according to Dumat et al. (2006) by inductively coupled plasma atomic emission spectrometry (ICP-AES) on an IRIS Intrepid II XXDL apparatus, following triacid ( $\mathrm{HF}, \mathrm{HCl}$ and $\mathrm{HNO}_{3}$ ) digestion of the solid samples. A standard reference soil (GRX2) was used to verify the digestion protocol and measurement accuracy. All the results correspond to the mean of two replicates. Values were the following: $\mathrm{Pb}=39800, \mathrm{Sb}=2095, \mathrm{Zn}=294, \mathrm{As}=288, \mathrm{Cu}=286$ and $\mathrm{Cd}=18.36 \mathrm{mg} \mathrm{kg}^{-1}$. This highly contaminated soil was used to establish a pollution concentration gradient to which earthworms were exposed.

The polluted soil was diluted with two uncontaminated control soils: referred to as S2 and S3, according to Uzu et al. (2009). The soil was then left in the open air to stabilize for one month (Schreck et al., 2011). The uncontaminated S2 had similar characteristics to polluted $\mathrm{S} 1 \mathrm{(pH}$, texture and OM \%) whereas S3 was poorly enriched in organic matter and more calcareous. This soil preparation procedure allowed both the influence of ITE concentration and soil type (organic matter concentration and $\mathrm{pH}$, in particular) on earthworm ecotoxicity to be studied. Table 1 provides details on the concentrations and some physico-chemical information of these three soils measured according to normalized procedures.

Table 2 shows the notations used and ITE concentrations in the soils used. When $\mathrm{S} 1$ is pure, the pollutant concentration is maximal, noted as $C_{5}-\mathrm{S} 1$. When the uncontaminated soils S2 and S3 are pure, the concentrations are minimal and noted as $C_{0}-\mathrm{S} 2$ and $C_{0}-\mathrm{S} 3$, respectively. The following notations were then used: $\left(C_{1}-\mathrm{S} 2, C_{2}-\mathrm{S} 2\right.$, $C_{3}-\mathrm{S} 2$ and $\left.C_{4}-\mathrm{S} 2\right)$ or $\left(C_{1}-\mathrm{S} 3, C_{2}-\mathrm{S} 3, C_{3}-\mathrm{S} 3\right.$ and $\left.C_{4}-\mathrm{S} 3\right)$ when mixtures of $(\mathrm{S} 1+\mathrm{S} 2)$ or $(\mathrm{S} 1+\mathrm{S} 3)$, respectively, were studied. For convenience, the different dilutions were referred to for their final total lead concentration: $C_{1}=100 ; C_{2}=825 ; C_{3}=1650$; and $C_{4}=4000 \mathrm{mg} \mathrm{kg}^{-1}$. The emission of particles from the recycling plant is the source of the S1 soil pollution. These PM sources were characterized and their solubility measured by Uzu et al. (2009). All the process particles contained the same major lead phases $\left(\mathrm{Pb}, \mathrm{PbS}, \mathrm{PbO}, \mathrm{PbSO}_{4}\right.$ and $\left.\mathrm{PbO}, \mathrm{PbSO}_{4}\right)$ but differed on the nature and amount of minor phases. The size distribution of the particles was previously determined by laser granulometric analyses using a Malvern Mastersizer S: the PM mainly contains fine particles ( $91 \%$ are less than $10 \mathrm{~mm}$ ). Their total element contents were determined by ICP-OES Intrepid II XXDL after heat digestion (Uzu et al., 2009): lead was the main metal (33.4\%) and the other metal contents were $\mathrm{Cd}, \mathrm{Sb}$, $\mathrm{As}, \mathrm{Cu}$ and $\mathrm{Zn}$ at 2.7, 1.8, 0.09, 0.09 and $0.7 \%$ respectively. The estimation of their metal solubility was performed using $0.01 \mathrm{M} \mathrm{CaCl}_{2}$ extraction procedure.

\subsection{Earthworms}

Two earthworm species (Eisenia hortensis and Lumbricus terrestris) were chosen in the experimental set-up. Eisenia hortensis is an epigeic species closely related to Eisenia fetida, which is currently used for normalized ecotoxicity tests (Fuller-Espie, 2010). Lumbricus terrestris is an anecic species that dominates earthworm biomass in various temperate ecosystems and strongly affects organic matter transformation and soil development (Maleri et al., 2008). Adult earthworms (L. terrestris and E. hortensis) were purchased from a local supplier (Decathlon ${ }^{\circledR}$, France). Before exposure experiment, earthworms were acclimatized during one week in the experiment conditions (temperature, obscurity, soil moisture...).

\subsection{Experimental set-up}

Small plastic Petri dishes (diameter $=8 \mathrm{~cm}$ and height $=3 \mathrm{~cm}$ ) were filled with $100 \mathrm{~g}$ of wet soils sieved to $2 \mathrm{~mm}$. Earthworms were added in the boxes: one earthworm by petri dish for $L$. terrestris and $E$. hortensis. Six experimental series were carried out simultaneously for each soil and each earthworm species, one series for each metal concentration. Each series consisted in seven replicates with either L. terrestris or E. hortensis and three boxes were used as controls without

Table 1

Detailed characteristics of each of three soil types used in this study.

\begin{tabular}{ll}
\hline Soil & Soil characteristics \\
\hline S1 & pH $=6$ \\
& Organic matter: $5.2 \%$ \\
& $12 \%$ clay, $47 \%$ silt and $41 \%$ sand \\
S2 & OH $=5.7$ \\
& Organic matter: $4.5 \%$ \\
S3 & $13 \%$ clay, $48 \%$ silt and $38 \%$ sand \\
& pH $=7.6$ \\
& Organic matter: $1 \%$ \\
& $22 \%$ clay, $26 \%$ silt and $52 \%$ sand \\
\hline
\end{tabular}


Table 2

Metals and metalloid concentrations in the studied soils $\left(\mathrm{mg} \mathrm{kg}^{-1}\right)$.

\begin{tabular}{llllllr}
\hline Concentrations & $\mathrm{Pb}$ & $\mathrm{Cd}$ & $\mathrm{Cu}$ & $\mathrm{Zn}$ & \multicolumn{1}{l}{$\mathrm{As}$} & $\mathrm{Sb}$ \\
\hline$C_{0}$ & 19.2 & 0.27 & 21.6 & 75.7 & 0.05 & 0.05 \\
$C_{1}$ & 100 & 0.31 & 22.3 & 76.2 & 0.7 & 5.3 \\
$C_{2}$ & 825 & 0.64 & 27.1 & 80.2 & 6 & 43.4 \\
$C_{3}$ & 1650 & 1 & 32.6 & 84.8 & 11.9 & 86.8 \\
$C_{4}$ & 4000 & 2.1 & 48.2 & 97.6 & 28.9 & 210.5 \\
\hline
\end{tabular}

earthworms. Earthworms were exposed for 14 days. The boxes were stored in a dark chamber at a constant temperature of $12{ }^{\circ} \mathrm{C}$. At the beginning of the experiment, soil moisture was measured and adjusted to $19 \%$, corresponding to $65 \%$ and $75 \%$ of water holding capacity respectively for S2 and S3, then checked regularly by weighing the Petri dishes and adjusted to the desired value by adding distilled water and mixing the soil (without destroying the casts).

\subsection{Ecotoxicity parameters}

To evaluate the impact of contaminated soils on earthworms, three endpoints were monitored: mortality, biomass changes and cast production (CP). Earthworm weight was determined at the beginning of the experiment, after 7 days and at the end of the exposure period. For this, earthworms were rinsed in distilled water and gently dried on filter paper (without gut voiding). Biomass changes were expressed as a percentage of the initial biomass.

According to Capowiez et al. (2010), CP is an ecologically meaningful and promising biomarker for ecotoxicity tests, but some aspects should be carefully considered for this marker to be widely used and accepted. First of all, preliminary tests need to be carried out to adapt (i) mesh size and test duration to the earthworm species under investigation and (ii) soil water content to soil texture. The key parameters are the soil moisture content and the initial soil particle size distribution. $\mathrm{CP}$ was therefore measured according to the protocol recently described by Capowiez et al. (2010) and modified by Dittbrenner et al. (2011). Casts were separated using a set of four sieves (diameter $=15 \mathrm{~cm}$ and mesh sizes $=5.6,4,3.15$, $2.5 \mathrm{~mm}$ ). The principle is that earthworm activity will modify soil granulometry leading to an increase in the amount of soil retained in some sieves (casting) and a decrease in others (soil consumption). All soil from each Petri dish, including the soil that adhered to the walls of the dishes which was removed with a knife, was sieved taking care not to break up the casts. The set of sieves was manually shaken for $10 \mathrm{~s}$. The soil retained in each sieve was weighed. The effect of earthworm bioturbation was then examined by determining the changes in the particle size distribution (PSD), i.e. weight of fresh soil in each sieve minus the corresponding weight of soil for the control soil (without earthworm). CP was measured immediately after the 14th day of exposure. It was expressed as cast fresh weight per earthworm fresh body mass per day.

\subsection{Metal bioaccumulation}

ITE concentrations in earthworm bodies were determined after acidic digestion. Invertebrates were digested with a mixture of $1 \mathrm{~mL} \mathrm{HNO}_{3} 70 \%$ and $0.5 \mathrm{~mL}$ of fluorhydric acid $51 \%$ in Teflon bombs placed on heating plates at $90{ }^{\circ} \mathrm{C}$ for 2 days. After evaporation, $1 \mathrm{~mL} \mathrm{H} \mathrm{H}_{2} \mathrm{O}_{2} 30 \%$ and $1 \mathrm{~mL}$ of $\mathrm{HNO}_{3} 70 \%$ were added and the Teflon bombs replaced on heating plates at $90{ }^{\circ} \mathrm{C}$ for 2 days. The samples were then evaporated at $50{ }^{\circ} \mathrm{C}$. Ultra-high purity water was used for dilutions. Solutions were stored at $4{ }^{\circ} \mathrm{C}$ in polyethylene tubes before analysis. ITE concentrations were measured by inductively coupled plasma-optical emission spectrometry ICP-OES (IRIS Intrepid II XXDL) or inductively coupled plasma-mass spectrometry ICP-MS (X Series II, Thermo Electron). Ten blank samples were submitted to the same treatment (mineralization and assay) for method control. They were performed to verify the non-contamination during acidic digestion. Each sample was analysed in triplicate. The detection limits for $\mathrm{Pb}, \mathrm{Cd}, \mathrm{Sn}, \mathrm{Sb}, \mathrm{As}, \mathrm{Cu}$ and $\mathrm{Zn}$ were $0.3,0.2,0.2,0.2$, $0.2,1.3$ and $2.2 \mu \mathrm{g} \mathrm{L}^{-1}$ respectively, whereas, the limits of quantification were about $0.4,0.3,0.3,0.4,0.3,2$ and $3 \mu \mathrm{g} \mathrm{L}^{-1}$ respectively for the same inorganic trace elements. Measurement accuracy was verified using reference material: lobster tissue (TORT-2) was used as a reference material for earthworm mineralization whereas standard soil reference material (from National Institutes of Standards and Technology: NIST) was used for soil acidic digestion. The concentrations found were within $95-102 \%$ of the certified values for all measured elements. Internal ITE concentrations were indicated as (IC). Following Nannoni et al. (2011), Bio Accumulation Factors (BAF) were calculated as the ratio of the element concentration in the earthworm (in $\mathrm{mg} \mathrm{kg}^{-1}$ of dry weight) to the total soil element content (in $\mathrm{mg} \mathrm{kg}^{-1}$ of dry weight).

\subsection{Micro-X-ray fluorescence $(\mu \mathrm{XRF})$ experiments}

In order to investigate the distribution of accumulated $\mathrm{Pb}$ within earthworm tissues, X-ray fluorescence micro-spectroscopy ( $\mu$-XRF) analysis was performed on transversal histological sections of $L$. terrestris earthworms in the intestinal region. For $\mu \mathrm{XRF}$ experiments, earthworms were exposed to the most polluted soil (S1) during 14 days and lead was the principal metal investigated because of its high content in S1. $\mu \mathrm{XRF}$ measurements were performed after a gut-voiding period on filter paper during five days. During the analysis the samples were fix and kept frozen using a Peltier freezing system. Experiments were carried out using a microscope (XGT7000, Horiba Jobin Yvon) equipped with an X-ray guide tube producing a finely focused beam with a $10 \mu \mathrm{m}$ or $100 \mu \mathrm{m}$ spot size (Rh X-ray tube, $30 \mathrm{kV}$ $1 \mathrm{~mA}$ equipped with an EDX detector), as described by Lapied et al. (2011).

\section{7. $\mathrm{CaCl}_{2}$ extraction}

To assess the available fraction of inorganic pollutants in the soil, extraction with neutral salts is the most useful indication (Menzies et al., 2007). A $0.01 \mathrm{M} \mathrm{CaCl}_{2}$ extraction procedure gives a good indication of lead availability. The $\mathrm{CaCl}_{2}$ procedure was performed on $\mathrm{S} 2+\mathrm{S} 1$ and $\mathrm{S} 3+\mathrm{S} 1$ for all concentrations. $30 \mathrm{~mL}$ of $0.01 \mathrm{M} \mathrm{CaCl}_{2}$ solution was mixed with $3 \mathrm{~g}$ of soil (1:10 solid solution ratio) in $50 \mathrm{~mL}$ polypropylene centrifugation tubes placed on a shaker table (Heidolph promax 1020) at 50 oscillations $\mathrm{min}^{-1}$ for $2 \mathrm{~h}, 20^{\circ} \mathrm{C}$. After extraction, the tubes were centrifuged at $10,000 \mathrm{~g}$ for $30 \mathrm{~min}$. The supernatant liquid was then filtered $(0.22 \mu \mathrm{m})$, acidified to $2 \%$ with distilled $\mathrm{HNO}_{3}\left(15 \mathrm{M}\right.$, suprapur 99.9\%) and stored at $4{ }^{\circ} \mathrm{C}$ before analysis. Extracted ITE concentrations were determined by inductively coupled plasma atomic emission spectrometry (ICP-AES) on IRIS Intrepid II XXDL apparatus.

\subsection{Statistical analyses}

Results were expressed as means \pm SD (standard deviation). The relationships between $\mathrm{CP}$ and earthworm fresh weight were assessed using linear regression. To study the effects of pollutants concentrations on $\mathrm{CP}$ or weight loss, we performed a one way ANOVA. All tests were carried out using the $\mathrm{R}^{\circledR} 2.14 .1$ package software Statistical differences were accepted when the probability of the result assuming the null hypothesis $(p)$ was less than 0.05 .

\section{Results}

\subsection{Mortality and biomass changes}

Throughout the experimental period, no earthworms died in the uncontaminated control soils $\left(C_{0}\right)$. Thus, this suggests that the experimental conditions were valid in terms of providing suitable media for earthworm survival. Regardless of the concentration of polluted soil applied, earthworm mortality was less than 5\% in S2 and no mortality was observed for S3. For both earthworm species, the most significant weight losses were always observed following incubation in polluted soil S1 (Fig. 1) and the mortality recorded in this $\mathrm{S} 1$ soil was about $10.5 \%$. After 14 days of exposure to increasing concentrations of ITE, the $L$. terrestris biomass was significantly reduced in S2 at concentrations $C_{3}$ and $C_{4}$ compared to the control group and increased significantly for $C_{1}$ and $C_{2}$. In contrast, no significant differences were found for worms incubated in the S3 soil, regardless of the pollutant concentration. Similar results were observed for E. hortensis (Fig. 1), but weight losses were only significant for the $C_{4}$ concentration in S2 $(-6.6 \%)$. No significant decreases in weight were observed for any pollutant concentration mixed with S3 control soil, however earthworm weight did significant increase after 14 days at concentrations $C_{2}, C_{3}$ and $C_{4}$.

\subsection{Cast production}

According to Fig. 2, both earthworms' species produced significantly less casts in the polluted soil S1 compared to the control group. For L. terrestris, CP was significantly lower compared to the control group at the $C_{4}$ concentration in $S 2$, with a decrease of $30.5 \%$. In contrast, no significant differences in $\mathrm{CP}$ were observed in S3 soil mixed with polluted soil compared to controls (Fig. 2). For E. hortensis, a significant decrease was observed for the $C_{3}$ and $C_{4}$ concentrations in S2, with a decrease in CP of approximately $65.5 \%$ and $99.5 \%$, respectively, compared to controls. As observed for L. terrestris, no significant differences were observed for S3 conditions (Fig. 2). 
Version définitive du manuscrit publiée dans / Final version of the manuscript published in :

Environmental Pollution (2012), Vol. 179, p. 232-241, DOI: 10.1016/j.envpol.2013.03.066

Journal homepage: http://www.elsevier.com/locate/envpol

a)

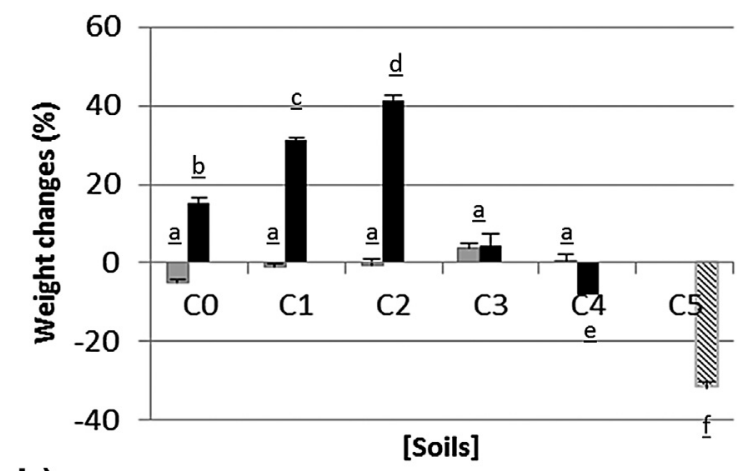

b)

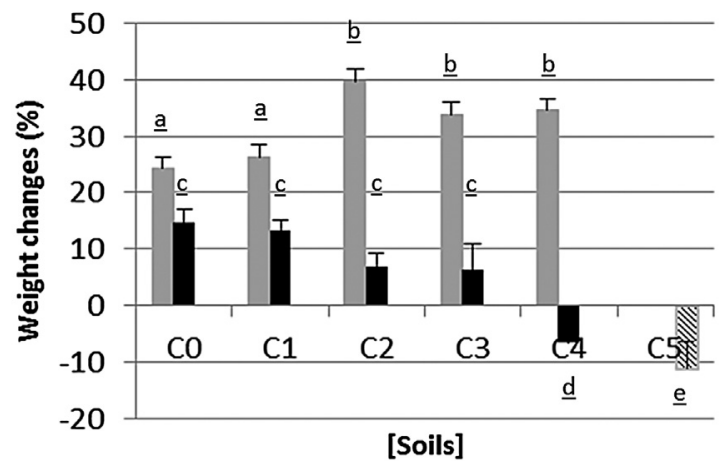

Fig. 1. Biomass changes as a percentage of the initial mass at the end of the 14 day experiment for Lumbricus terrestris (a) and Eisenia hortensis (b) incubated in different concentrations of polluted soil (a,b,c,d,e,f weight changes significantly different $(p \leq 0,05)$ for one way ANOVA.).

\subsection{Metal bioaccumulation}

The mean concentrations of $\mathrm{Pb}, \mathrm{Cd}, \mathrm{Cu}, \mathrm{As}, \mathrm{Sb}$, and $\mathrm{Zn}$ (expressed as $\mathrm{mg} \mathrm{kg}^{-1}$ dry weight) in L. terrestris and E. hortensis specimens are reported in Table 3 for S1 and in Fig. 3 for S2 and S3. Differences were observed between the element contents in tissues and between the two earthworm species for all the concentrations. Except for $\mathrm{Zn}$, the ITE concentration in $L$. terrestris and E. hortensis exposed to $C_{2}, C_{3}, C_{4}$ was higher than in the control group, in both soil types. Internal concentrations of pollutant (except for $\mathrm{Zn}$ and $\mathrm{Cd}$ ) in L. terrestris were significantly higher in earthworms incubated in S2 than in S3 (Fig. 3). IC of Pb and Sb in E. hortensis were higher in earthworms incubated in S2 than in S3 (Fig. 3). Table 4 shows all the bioaccumulation factors (BAF) for $L$. terrestris and $E$. hortensis. For both species, BAF values were ranked as follows: $\mathrm{Cd}>\mathrm{Zn}$ $>>\mathrm{As}>\mathrm{Cu}>\mathrm{Pb} \mathrm{Sb}$. Only $\mathrm{Cd}$ and $\mathrm{Zn}$ had BAF values above 1, indicating that the two elements were not only taken up but also bio-accumulated in the earthworms. For the other ITE, BAF values were below 1 .

\subsection{Lead distribution within earthworm tissues: $\mu X R F$}

The distribution of accumulated $\mathrm{Pb}$ within transversal histological sections of earthworms in the intestinal region was performed by $\mu$-XRF and microscopy observations were given in (Fig. 4). Results showed that even after depuration, $\mathrm{Pb}$ remains localized in the gut wall and above all in the longitudinal muscles of exposed earthworms (Fig. 4). The mean XRF spectra generated from the hyperspectral maps and the presence of the fluorescence lines a)
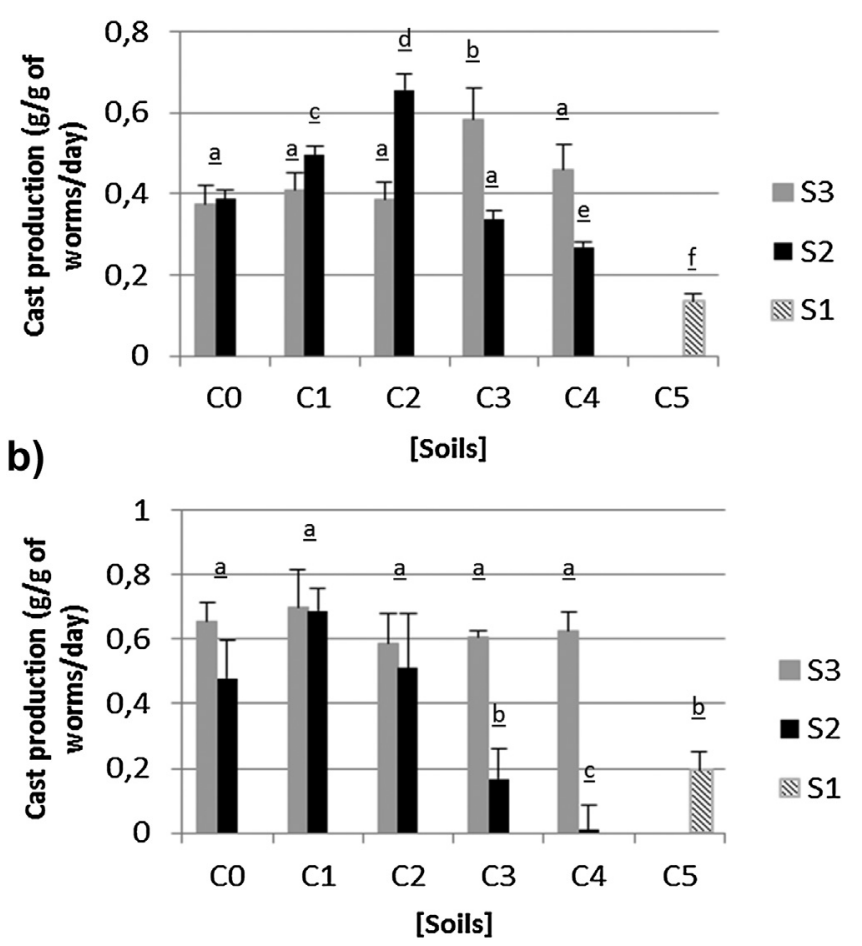

Fig. 2. Casts produced over the course of the experiment $\left(\mathrm{g} \mathrm{g}^{-1}\right.$ of earthworm day ${ }^{-1}$ ) by Lumbricus terrestris (a) and Eisenia hortensis (b) incubated in different concentrations of polluted soil (a,b,c,d,e cast production significantly different $(p \leq 0,05)$ for one way ANOVA.).

at $10.5 \mathrm{KeV}$ ( $\mathrm{Pb} \mathrm{L} \alpha$ emission line) and $12.6 \mathrm{KeV}$ ( $\mathrm{Pb} \mathrm{L} \beta$ emission line) confirmed the presence of $\mathrm{Pb}$ (Fig. 4).

\section{5. $\mathrm{CaCl}_{2}$ extraction}

Table 5 shows the results of $\mathrm{CaCl}_{2}$ metal extraction from $\mathrm{S} 1, \mathrm{~S} 2$ and S3 (expressed as a percentage of the soil concentration) and from the PM emission (expressed as the percentage of total metal content.). The fraction of extractable ITE was always higher from S2 than S3 for all the considered ITE. Table 5 reported the values only for $C_{4}$ concentration because ITE extractable fraction was not detectable by ICP-OES for $C_{1}, C_{2}$ and $C_{3}$ concentrations.

\section{Discussion}

\subsection{Viability and ecotoxicity}

This experiment focused on the effects of a cocktail of ITE (lead being the major pollutant), on earthworm health and behaviour. Lethality effects were only observed in the soil containing the highest ITE concentrations $\left(40,000 \mathrm{mg} \mathrm{Pb} \mathrm{kg}^{-1}\right.$ and other ITE, see Table 1). These results confirm that the control experimental conditions were suitable for earthworm survival and that PM polluted soil is not toxic enough to have lethal effects on earthworms until

Table 3

Internal concentrations of metals in Lumbricus terrestris and Eisenia fetida.

\begin{tabular}{|c|c|c|c|c|c|c|c|}
\hline & & $\mathrm{Pb}$ & $\mathrm{Cd}$ & $\mathrm{Cu}$ & $\mathrm{Zn}$ & As & $\mathrm{Sb}$ \\
\hline \multirow[t]{2}{*}{$\mathrm{S} 1$} & Lumbricus terrestris & 8659 & 26.2 & 85.3 & 503.2 & 24 & 695 \\
\hline & Eisenia hortensis & 932 & 7.2 & 23.9 & 130.6 & 8.2 & 45.9 \\
\hline
\end{tabular}


Version définitive du manuscrit publiée dans / Final version of the manuscript published in :

Environmental Pollution (2012), Vol. 179, p. 232-241, DOI: 10.1016/j.envpol.2013.03.066

Journal homepage: http://www.elsevier.com/locate/envpol

a)

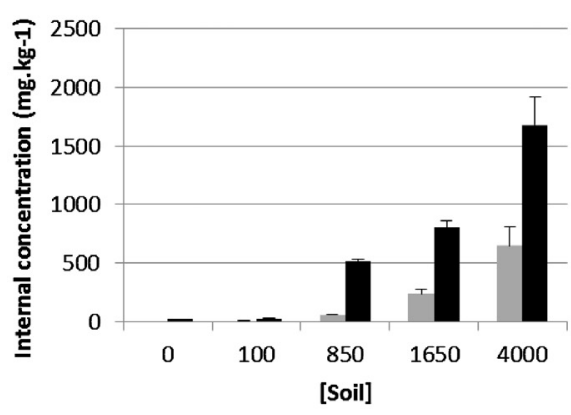

a)

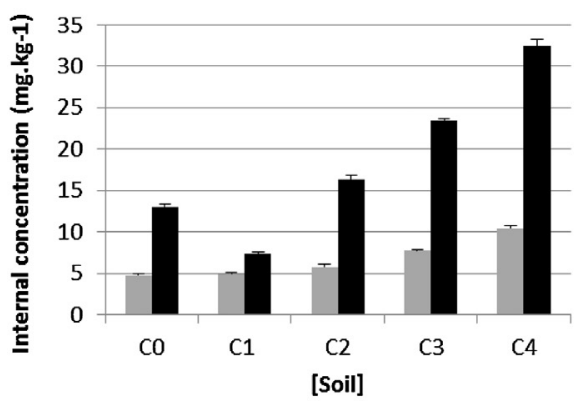

a)

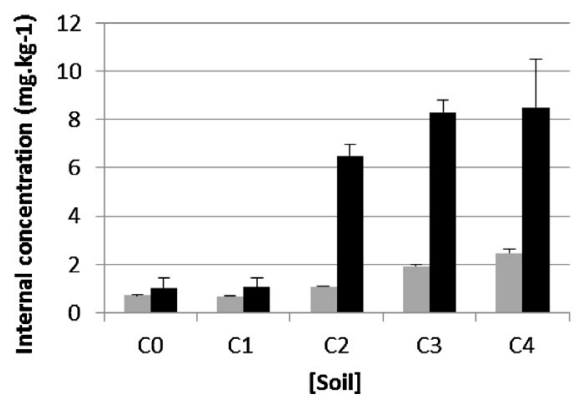

a)

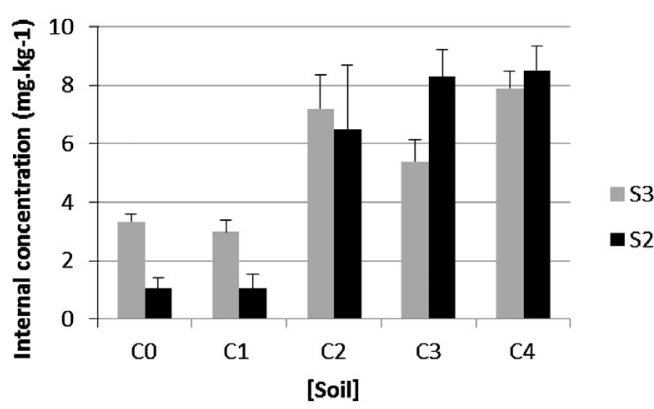

a)

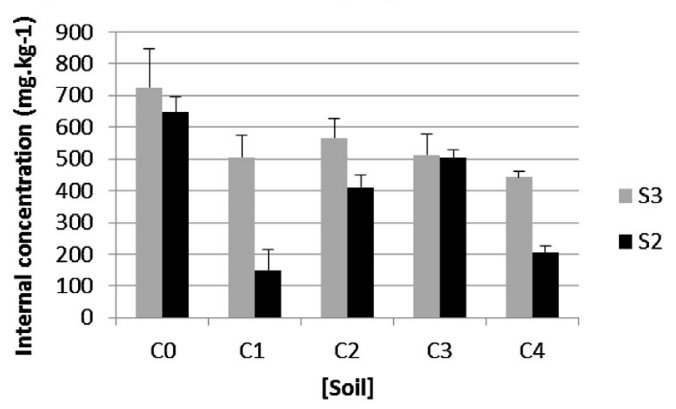

a)

[Sb]

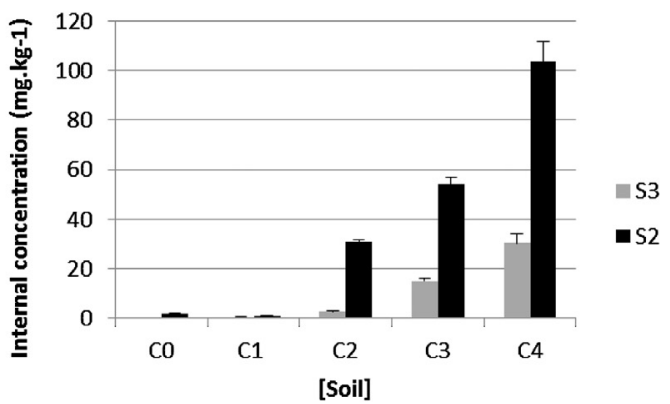

Fig. 3. Total internal content of each element in Lumbricus terrestris (a) and Eisenia hortensis (b) incubated in S2 and S3 and different concentrations of polluted soil.

$4000 \mathrm{mg} \mathrm{Pb} \mathrm{kg}{ }^{-1}$. Davies et al. (2003) measured a $\mathrm{LC}_{50}$ of $5311 \mathrm{mg} \mathrm{Pb} \mathrm{kg}^{-1}$ for earthworms exposed for 14 days to nitrate lead spiked soil. This lower lethal concentration could be explained by the different experimental conditions. The stability and lack of lethality for biological organisms observed here were previously reported by Schreck et al. (2011) working with the same long-term polluted soil.

However, several sublethal effects were observed in this Petri dish experiment. Changes to physiological and behavioural endpoints such as biomass and $\mathrm{CP}$ were observed at the highest concentrations. These effects suggest that atmospheric pollution can have a significant impact on earthworm physiology (locomotion, nutrition...). As shown in Table 6, ITE can impact earthworm physiology and ecotoxicity depends on earthworm species and soil characteristics. Indeed, Reinecke et al. (2001) studied the cocoon viability of three earthworm species following exposure to substrates contaminated with lead nitrate, cadmium sulphate and zinc sulphate for 36 months. They concluded that different earthworm species can have significantly different sensitivity to ITE. As reported by Ernst et al. (2008), soil properties can modify metal bioavailability and their subsequent impacts on earthworm physiology and behaviour. In the present study we compared a clayed, organic matter rich, acidic soil (S2) with a higher $\mathrm{pH}$ sandy soil (S3), and showed that S3 had less impact on earthworm health. Furthermore, extraction with $\mathrm{CaCl}_{2}$ (Table 4) to simulate solidsolution transfer for pollutants, showed that metals were more mobile in the more acidic soil S2 which suggests that soil $\mathrm{pH}$ plays an important role. According to Bradham et al. (2006), soil pH can increase the fraction of soluble metals. Vandecasteele et al. (2004) reported that, compared to the surrounding environment, earthworm biomass was four times lower in contaminated dredged sediment-derived heavy clay soils, but comparable when earthworms were incubated in sandy loam soils. The same results were observed in the present experiment.

\subsection{Metal bioaccumulation}

Excepted for $\mathrm{Zn}$, a significant $\left(r^{2}\right)$ positive linear correlation was observed between ITE concentration in earthworms and total contents in soil, for both earthworm species (Table 7). Logically, the highest ITE concentrations were found in earthworms incubated in S1 (historically polluted soil). These findings are consistent with previous studies (Morgan and Morgan, 1993, 1998). Unlike the other ITE, there was no linear relationship between the internal $\mathrm{Zn}$ 
Version définitive du manuscrit publiée dans / Final version of the manuscript published in :

Environmental Pollution (2012), Vol. 179, p. 232-241, DOI: 10.1016/j.envpol.2013.03.066

Journal homepage: http://www.elsevier.com/locate/envpol

b)

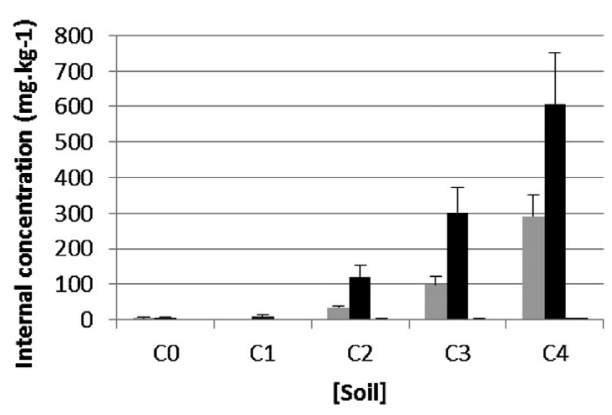

b)

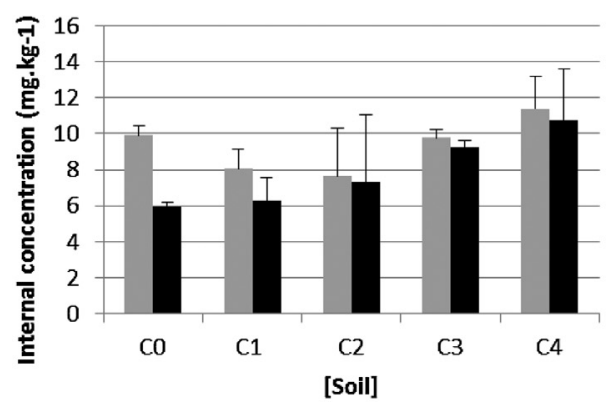

b)

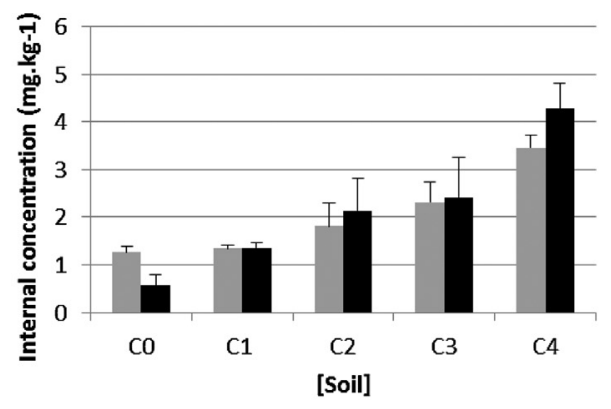

b)

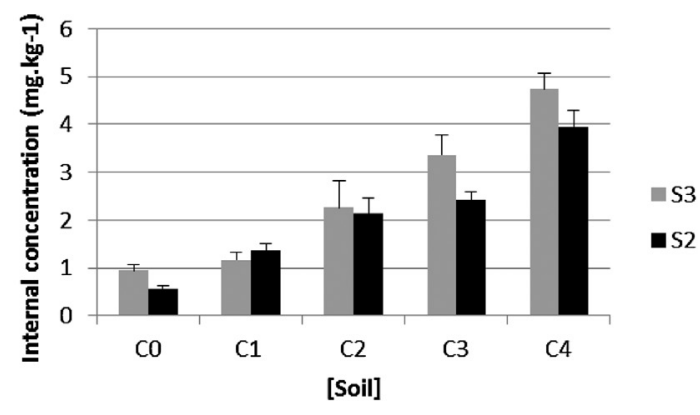

b)

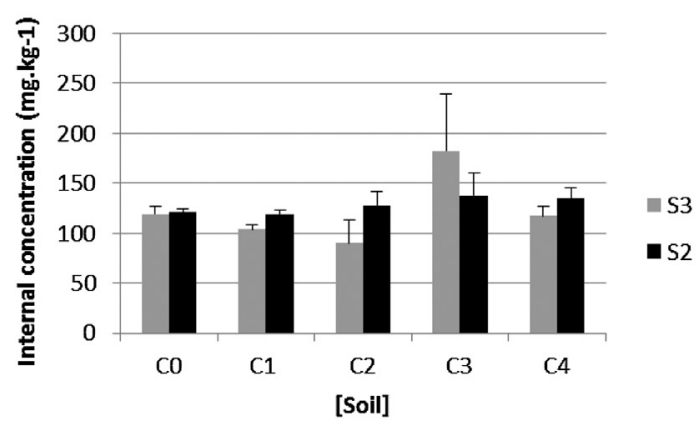

b)

[Sb]

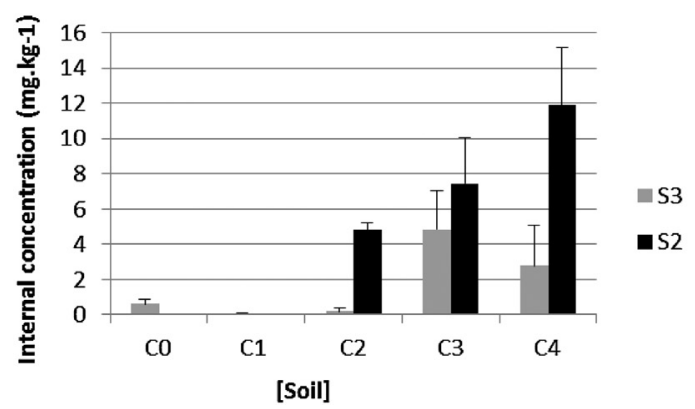

Fig. 3. (continued).

concentration in earthworms and its total soil content. Indeed $\mathrm{Zn}$ is an essential element and its internal level is regulated directly by earthworms (Nannoni et al., 2011). It has been suggested that in earthworms Zn plays essential roles (respiratory control and tissue growth, development and regeneration processes) suggesting that is specifically taken up by earthworms (Wròblewski et al., 1979; Morgan, 1984). In addition, the bioavailable fraction estimated by $0.01 \mathrm{M} \mathrm{CaCl}_{2}$ extraction (Table 4 ) showed that $\mathrm{Zn}$ should be highly bioavailable to earthworms (in comparison with other metals), even if its soil concentration was low. In this present study, the BAF for $\mathrm{Zn}$ was above 1 , which indicates that $\mathrm{Zn}$ was bioaccumulated by the two earthworm species. The efficiency of $\mathrm{Zn}$ accumulation probably relates to a necessity for a stored pool of available $\mathrm{Zn}$ in anticipation of future physiological demand (Nannoni et al., 2011). At such high internal exposure levels, earthworms must either suffer from Zn toxicity or have adapted to resist toxicity, resulting in a higher capacity to store this element (Hobbelen et al., 2006).

Despite its toxicity, Cd was also highly accumulated by earthworms. This phenomenon could be explained by its high mobility and availability in soil together with its chemical analogy with $\mathrm{Zn}$ (Li and Thornton, 2001; Nannoni et al., 2011). In a smelter contaminated area in northern Kosovo, Nannoni et al. (2011) previously observed that earthworms bioaccumulate both $\mathrm{Zn}$ and $\mathrm{Cd}$. Thus, internal concentrations and bioaccumulation factor values both suggest that earthworms could be used as bioindicators of ITE pollution in soils. In addition, less uptake and bioaccumulation of all ITE was observed in E. hortensis than in L. terrestris. Indeed, Suthar et al. (2008) reported that a speciesspecific metal accumulation pattern depending on the earthworm ecological type could be observed. They suggested that speciesspecific feeding behaviour, earthworm niche structure, the ecological category of inhabiting earthworms and even the horizontal distribution of contaminants in soil layers are major determinants for metal accumulation patterns in soil dwelling earthworms. The well-characterized differences in burrowing patterns between endogeic and anecic worms could influence the patterns of metal bioaccumulation, although other factors may also contribute (Suthar et al., 2008). Nannoni et al. (2011) did not observe any significant differences in terms of metal uptake and bioaccumulation between different species within a same ecological group. Lukkari and Haimi (2005) showed that Eisenia fetida (epigeic) appeared to be more tolerant to metals than $A$. tuberculata (endogeic) and seemed to regulate the tissue metal concentrations more strictly. Morgan and Morgan (1999) studied the accumulation 


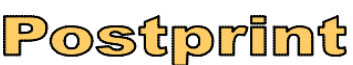

Version définitive du manuscrit publiée dans / Final version of the manuscript published in :

Environmental Pollution (2012), Vol. 179, p. 232-241, DOI: 10.1016/j.envpol.2013.03.066

Journal homepage: http://www.elsevier.com/locate/envpol

Table 4

Heavy metal bioaccumulation factors (BAF) for L. terrestris and E. hortensis.

\begin{tabular}{cllllllll}
\hline & & Sols & $\mathrm{Pb}$ & $\mathrm{Cd}$ & $\mathrm{Cu}$ & $\mathrm{Zn}$ & $\mathrm{As}$ & $\mathrm{Sb}$ \\
\hline Lumbricus & $\mathrm{S} 2$ & $C_{0}$ & 1.2 & 3.9 & 0.6 & 8.55 & $\mathrm{ND}$ & $\mathrm{ND}$ \\
terrestris & & $C_{1}$ & 0.19 & 3.33 & 0.33 & 1.97 & 1.454 & 0.19 \\
& & $C_{2}$ & 0.62 & 10.1 & 0.6 & 5.12 & 1.090 & 0.71 \\
& & $C_{3}$ & 0.41 & 8.13 & 0.27 & 5.93 & 0.695 & 0.78 \\
& & $C_{4}$ & 0.42 & 4.07 & 0.67 & 2.10 & 0.294 & 0.49 \\
& $\mathrm{~S} 1$ & $C_{5}$ & 0.31 & 1.8 & 0.42 & 2.27 & 0.121 & 0.46 \\
& $\mathrm{~S} 3$ & $C_{0}$ & 0.22 & 12.33 & 0.22 & 9.58 & $\mathrm{ND}$ & $\mathrm{ND}$ \\
& & $C_{1}$ & 0.06 & 9.46 & 0.22 & 6.63 & 0.93 & 0.10 \\
Eisenia & & $C_{2}$ & 0.07 & 11.16 & 0.21 & 7.05 & 0.18 & 0.06 \\
& & $C_{3}$ & 0.14 & 5.28 & 0.23 & 6.04 & 0.16 & 0.17 \\
& & $C_{4}$ & 0.16 & 3.77 & 0.21 & 4.53 & 0.08 & 0.14 \\
& $\mathrm{~S} 1$ & $C_{5}$ & 0.12 & 1.06 & 0.17 & 1.14 & 0.04 & 0.19 \\
& $\mathrm{~S} 2$ & $C_{0}$ & 0.28 & 2.11 & 0.27 & 1.60 & $\mathrm{ND}$ & $\mathrm{ND}$ \\
& & $C_{1}$ & 0.07 & 4.29 & 0.28 & 1.56 & 1.87 & $\mathrm{ND}$ \\
& & $C_{2}$ & 0.14 & 3.30 & 0.27 & 1.59 & 0.35 & 0.11 \\
& & $C_{3}$ & 0.18 & 2.37 & 0.28 & 1.62 & 0.20 & 0.08 \\
& & $C_{4}$ & 0.15 & 1.89 & 0.22 & 1.38 & 0.14 & 0.05 \\
& $\mathrm{~S} 1$ & $C_{5}$ & 0.03 & 0.40 & 0.07 & 0.44 & 0.05 & 0.04 \\
& $\mathrm{~S} 3$ & $C_{0}$ & 0.26 & 3.49 & 0.45 & 1.57 & $\mathrm{ND}$ & $\mathrm{ND}$ \\
& & $C_{1}$ & 0.003 & 3.70 & 0.36 & 1.36 & 1.85 & $\mathrm{ND}$ \\
& & $C_{2}$ & 0.04 & 3.50 & 0.28 & 1.12 & 0.30 & 0.004 \\
& & $C_{3}$ & 0.06 & 3.29 & 0.30 & 2.15 & 0.19 & 0.05 \\
& & $C_{4}$ & 0.07 & 2.26 & 0.23 & 1.2 & 0.12 & 0.01 \\
& $\mathrm{~S} 1$ & $C_{5}$ & 0.02 & 0.38 & 0.09 & 0.44 & 0.007 & 0.004 \\
\hline
\end{tabular}

of ITE by two ecologically contrasting earthworm species and found that $\mathrm{Cd}, \mathrm{Cu}$ and $\mathrm{Pb}$ concentrations were significantly higher in A. caliginosa (endogeic) than in L. rubellus (epigeic). However, concerning $\mathrm{Zn}$ accumulation, a difference between the two earthworm species was only observed at the lowest soil concentrations, suggesting differences in metal behaviour inside the earthworms, mostly related to elimination mechanisms (Morgan and Morgan, 1999). Internal concentrations and bioaccumulation factors were also different depending on the soil characteristics. According to our results, soil properties influence ITE bioavailability in relation to mobility (solid-solution transfer) and consequently the mechanisms of transfer (ingestion or transdermal uptake). van Gestel et al. (2011) reported that Mo uptake by earthworms is affected by soil $\mathrm{pH}$, with the highest uptake levels occurring at a $\mathrm{pH}=4$.
Table 5

The lead fraction extractible using the $0.01 \mathrm{M} \mathrm{CaCl}_{2}$ procedure in $\mathrm{PM}$ and $\mathrm{S} 1$ and at the $\mathrm{C}_{4}$ concentration in S3 and S2.

\begin{tabular}{lclcl}
\hline Soil & \multicolumn{4}{l}{ Metal extractable by $\mathrm{CaCl}_{2}$ (\% of total metal content) } \\
\cline { 2 - 5 } & $\mathrm{Zn}$ & $\mathrm{Cu}$ & $\mathrm{Cd}$ & $\mathrm{Pb}$ \\
\hline S1 & $1.91 \pm 0.6$ & $0.5 \pm 0.1$ & $1.1 \pm 0.5$ & $0.3 \pm 0.1$ \\
S2 & $5.2 \pm 0.4$ & $1.9 \pm 0.2$ & $4.5 \pm 0.1$ & $0.5 \pm 0.05$ \\
S3 & $4.1 \pm 02$ & $4.9 \pm 0.4$ & $4 \pm 0.1$ & $0.3 \pm 0.05$ \\
PM & $3.1 \pm 0.8$ & $\mathrm{ND}$ & $9.8 \pm 0.4$ & 0.01 \\
\hline
\end{tabular}

*Note: ITE extractable fraction was not detectable by ICP-OES for $C_{1}, C_{2}$ and $C_{3}$ concentrations.

Díez-Ortiz et al. (2010) also found that BAF total values for metal uptake in $E$. andrei correlated with the soil organic matter content. In the present experiment, ITE were generally more bioavailable in S2 which was acidic and enriched in organic matter and uptake of $\mathrm{Pb}, \mathrm{Cu}, \mathrm{Sb}$ and As by earthworms (especially for $L$. terrestris) was also higher when they were incubated in this soil type. As reported by Nannoni et al. (2011), organic matter is the main food source for earthworms and consequently represents an important source of ITE, which are largely bound to this component and later absorbed in the gut. Cecchi et al. (2008) observed a strong association of lead with the soil organic matter from a historically polluted soil impacted by process particles from lead recycling batteries. Thus, S2, enriched in organic matter, was a more important source of toxic ITE than S3 for the two species in the study. In contrast, the same proportion of $\mathrm{Cd}$ and $\mathrm{Zn}$, which are more mobile in soils, bioaccumulated regardless of the soil type. These two ITE are more present in soluble and extractable fractions, allowing an easy uptake in sandy soil.

\subsection{Uptake mechanisms and ecotoxicity test sensitivity}

Even at very low metal concentration in solution (maximum $0.5 \%$ of lead was extracted by $\mathrm{CaCl}_{2}$ for more acidic soil S2), the absorption of lead by earthworms was observed. Our hypothesis is therefore a strong absorption of metals from solid particles throughout the gut and only a small absorption achieved throughout teguments. Depending on ITE type, the mechanism by

(a)

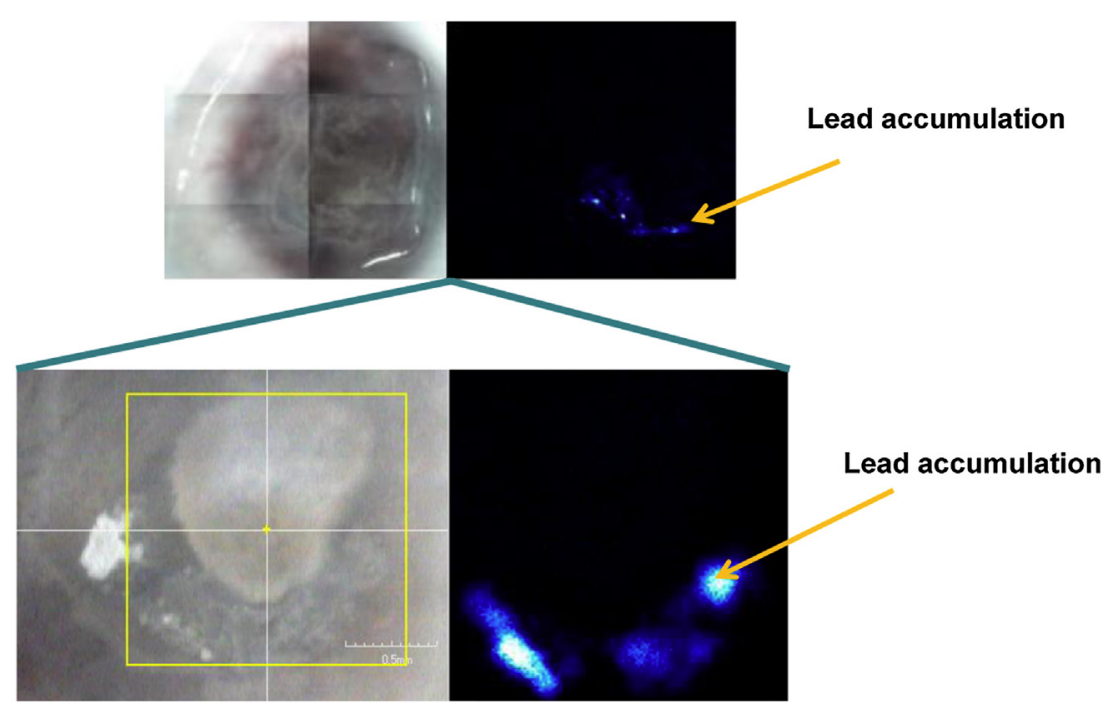

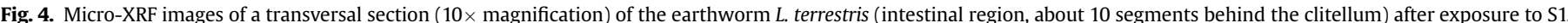

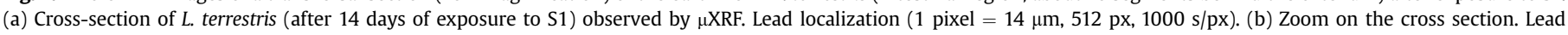
localization ( 1 pixel $=12 \mu \mathrm{m}, 128 \mathrm{px}, 1000 \mathrm{~s} / \mathrm{px}$ ) in the gut wall and the longitudinal muscles of earthworm. 
Version définitive du manuscrit publiée dans / Final version of the manuscript published in :

Environmental Pollution (2012), Vol. 179, p. 232-241, DOI: 10.1016/j.envpol.2013.03.066

Journal homepage: http://www.elsevier.com/locate/envpol

Table 6

Review of ITE impact on earthworms.

\begin{tabular}{|c|c|c|c|c|c|c|}
\hline References & ITE & Soil total content & Time of exposure & Earthworm species & Soil preparation & Observation \\
\hline Zheng and Li, 2009 & $\mathrm{~Pb}$ & $0-7500 \mathrm{mg} \mathrm{kg}^{-1}$ & 14 days & Pheretima guillelmi & $\begin{array}{l}\text { Soil spiked with lead } \\
\text { nitrate solution }\end{array}$ & $\begin{array}{l}\text { - } \mathrm{LC} 50=4300 \mathrm{mgPb} \mathrm{kg} \\
\text { - Biomass and locomotion } \\
\text { decreased at } 2800 \mathrm{mgPb} \mathrm{kg}^{-1} \text { soil }\end{array}$ \\
\hline $\begin{array}{l}\text { Nahmani } \\
\text { et al., 2007a,b }\end{array}$ & $\begin{array}{l}\mathrm{Cd}, \mathrm{Cu}, \mathrm{Fe}, \mathrm{Pb}, \\
\mathrm{Zn}, \mathrm{Ag}, \mathrm{Al}, \mathrm{Ba}, \mathrm{Sr}\end{array}$ & $\begin{array}{l}30-42,100 \mathrm{mgPb} \mathrm{kg}^{-1} \\
120-53,400 \mathrm{mgZn} \mathrm{kg}^{-1} \\
0.5-347 \mathrm{mgCd} \mathrm{kg}^{-1}\end{array}$ & $\begin{array}{l}7,14,21,28 \text { and } \\
42 \text { days }\end{array}$ & Eisenia fetida & $\begin{array}{l}\text { Historically polluted } \\
\text { soils }\end{array}$ & $\begin{array}{l}\text { - Effect on earthworm survival, } \\
\text { body weight, cocoon production } \\
\text { and hatching } \\
\text { - Those effects are influenced } \\
\text { by soils parameters (texture, } \\
\text { pH, }[\mathrm{Ag}],[\mathrm{Cd}] \ldots \text { ) }\end{array}$ \\
\hline $\begin{array}{l}\text { Lukkari and } \\
\text { Haimi, } 2005\end{array}$ & $\mathrm{Cu}, \mathrm{Zn}$ & $\begin{array}{l}2-246 \mathrm{mgCu} \mathrm{kg} \\
13-453 \mathrm{mgZn} \mathrm{kg}\end{array}$ & $48 \mathrm{~h}-14$ days & $\begin{array}{l}\text { Aporrectodea } \\
\text { tuberculata }\end{array}$ & $\begin{array}{l}\text { Soil spiked with copper } \\
\text { and zinc solution and } \\
\text { field soils }\end{array}$ & $\begin{array}{l}\text { - Artificial soils: }(\mathrm{Cu} / \mathrm{Zn}) \\
\quad \text { LC50 }=134 / 234 \mathrm{mg} \mathrm{kg}^{-1} \text { soil } \\
\text { - Field soils: }(\mathrm{Cu} / \mathrm{Zn}) \\
\text { - LC50 }=333 / 582 \mathrm{mg} \mathrm{kg}^{-1} \text { soil } \\
\text { - Avoidance test: } 80 \% \text { at } \\
\quad 79 / 138(\mathrm{Cu} / \mathrm{Zn}) \mathrm{mg} \mathrm{kg}^{-1} \text { soil }\end{array}$ \\
\hline Wu et al., 2012 & $\mathrm{~Pb}, \mathrm{Cd}$ & $\begin{array}{l}0.1-10 \mathrm{mgCd} \mathrm{kg}^{-1} \\
5-500 \mathrm{mgPb} \mathrm{kg}^{-1}\end{array}$ & 7 days & Eisenia fetida & $\begin{array}{l}\text { Soil spiked with lead } \\
\text { and cadmium solution }\end{array}$ & $\begin{array}{l}\text { - } \mathrm{Cd}+\mathrm{Pb} \text { : inhibit cellulase activity } \\
\text { - For low [Cd], addition of } \\
\mathrm{Pb}=\nearrow \mathrm{DNA} \text { damages } \\
\text { - For high [Cd], addition of } \\
\mathrm{Pb}=\searrow \text { DNA damages }\end{array}$ \\
\hline Li et al., 2008 & $\mathrm{Cd}, \mathrm{Zn}$ & $\begin{array}{l}0.1 \mu \mathrm{M}-10 \mu \mathrm{MCd} \\
0-1000 \mathrm{nn}\end{array}$ & 2 days & Eisenia fetida & $\begin{array}{l}\text { Cattle manure spiked } \\
\text { with simulated soil } \\
\text { solution }\end{array}$ & $\begin{array}{l}\text { - LC } 50=145 \mu \mathrm{M} \mathrm{Zn} \\
\text { - LC } 50=316 \mu \mathrm{M} \mathrm{Zn} \text { with } \\
\text { pre exposure of Cd }(1 \mu \mathrm{M}) \\
\text { - Cd uptake is regulated by Ca }\end{array}$ \\
\hline Jones et al., 2009 & $\mathrm{~Pb}$ & $300-2249 \mathrm{mgPb} / \mathrm{kg}$ & 4-90 days & Eisenia fetida & $\begin{array}{l}\text { Soil spiked with lead } \\
\text { nitrate solution }\end{array}$ & $\begin{array}{l}\text { - LC50 = } 2490 \mathrm{mgPb} \mathrm{kg}^{-1} \text { soil } \\
\text { - Effect on reproduction } \\
\text { (cocoon count and juvenile } \\
\text { count) at } 400 \mathrm{mgPb} \mathrm{kg}^{-1} \text { soil }\end{array}$ \\
\hline Owojori et al., 2008 & $\mathrm{Zn}$ & $0-750 \mathrm{mgZn} \mathrm{kg}{ }^{-1}$ & 28 days & Eisenia fetida & $\begin{array}{l}\text { Soil spiked with } \mathrm{ZnCl}_{2} \\
\text { and } \mathrm{NaCl} \text { solution }\end{array}$ & $\begin{array}{l}\text { - Mortality observed at } 750 \\
\text { mgZn } \mathrm{kg}^{-1} \text { soil } \\
\text { - Cocoon viability decreased } \\
\text { at } 500 \mathrm{mgZn} \mathrm{kg}^{-1} \text { soil } \\
\text { - } \nearrow \text { toxic effects with salinity }\end{array}$ \\
\hline
\end{tabular}

which earthworms are exposed can vary: direct soil ingestion versus transfer through the teguments (Vijver et al., 2003). The study of lead localization in earthworm tissues by $\mu$ XRF have bring precious information about lead distribution in exposed earthworms and could bring hypothesis on the uptake way of $\mathrm{Pb}$. Actually, as showed by the Fig. 4 , Pb remains localized in the gut wall and the longitudinal muscles of exposed earthworms. These kind of observations were recently reported by Kılıç (2011) working with autometallography in the same earthworm species: their observations revealed that heavy metals were found to be accumulated mainly in circular and longitudinal muscles of gut. By the way, ITE absorption by earthworms often depends on the proportions of reducible and oxidable fractions in the soil, suggesting also that the intestine is likely the most important uptake route (Nannoni et al., 2011). If bioavailable ITE concentrations are high in the solid soil phase and low in the soil solution, the absolute uptake of metals could be higher via the gut exposure route than via the dermal exposure route (Hobbelen et al., 2006) (Fig. 5). It is possible that ITE which bind strongly to organic matter in earthworm food, are taken up in the gut, as was found in this study for S2. However, as previously mentioned, the water soluble fraction plays an important role especially for the most mobile elements such as $\mathrm{Cd}$ and $\mathrm{Zn}$, suggesting that dermal uptake is considerable, especially in acidic soils such as the experimental S2. To conclude, Cœurdassier et al. (2002) suggested that digestive and cutaneous contamination routes for $\mathrm{Cd}$ are responsible for sublethal toxic effects on snail growth in laboratory bioassays. However, cutaneous transfer of Cd was thought to be a secondary intoxication pathway, compared to digestive absorption, in the accumulation and induction of toxic effects in natural conditions.

Finally, antagonistic and synergistic phenomena between ITE can also occur. Wu et al. (2012) recently reported that $\mathrm{Cd}$ and $\mathrm{Pb}$ have combined and complex toxicological effects on earthworms. Cd bioavailability is often modified by its competitive sorption with $\mathrm{Pb}$ in soil fractions. Li et al. (2008) found that the presence of $\mathrm{Pb}$ significantly decreased the percentage of $\mathrm{Cd}$ in the cytosolic fraction but increased it in the cell membrane fraction of $E$. fetida, which could influence $\mathrm{Cd}$ bioaccumulation and toxicity. In the case of acute toxicity due to a cocktail of metals on an estuarine meiobenthic harpacticoid copepod, the mixture had a significantly greater than additive effect on survival, with the mixture being more toxic than that expected by simple additivity of the toxic effects of each metal (Hagopian et al., 2001). In order to assess ITE ecotoxicity, it is necessary to perform several complementary tests with various sensitivity levels. Indeed, the use of internal ITE concentrations in earthworms appears to be an effective and sensitive indicator of soil contamination, even in the case of pollution due to atmospheric fallout deposition near a lead recycling factory. This extractable fraction could become a good predictor of ITE bioavailability and thus ecotoxicity in soils, taking into account soil properties, ITE type and mobility. Lukkari and Haimi (2005) reported that a battery of tests on earthworms (avoidance, acute toxicity and reproduction tests) can be an efficient tool to assess the ecological risks of contaminated soils. However, careful choice of

Table 7

Linear correlation coefficients between the internal heavy metal concentration in earthworms and the total element content in the soil.

\begin{tabular}{llllllll}
\hline Soil & Species & $\mathrm{Pb} R^{2}$ & $\mathrm{Cd} R^{2}$ & $\mathrm{Cu} R^{2}$ & $\mathrm{Zn} R^{2}$ & As $R^{2}$ & $\mathrm{Sb} R^{2}$ \\
\hline $\mathrm{S} 2$ & Lumbricus terrestris & 0.9987 & 0.9522 & 0.9866 & 0.252 & 0.9589 & 0.9996 \\
& Eisenia hortensis & 0.8454 & 0.85 & 0.939 & 0.0809 & 0.975 & 0.9967 \\
$\mathrm{~S} 3$ & Lumbricus terrestris & 0.9986 & 0.9336 & 0.9992 & 0.5137 & 0.9962 & 0.9993 \\
& Eisenia hortensis & 0.8752 & 0.7237 & 0.9827 & 0.0114 & 0.9943 & 0.7371 \\
\hline
\end{tabular}


Environmental Pollution (2012), Vol. 179, p. 232-241, DOI: 10.1016/j.envpol.2013.03.066 Journal homepage: http://www.elsevier.com/locate/envpol

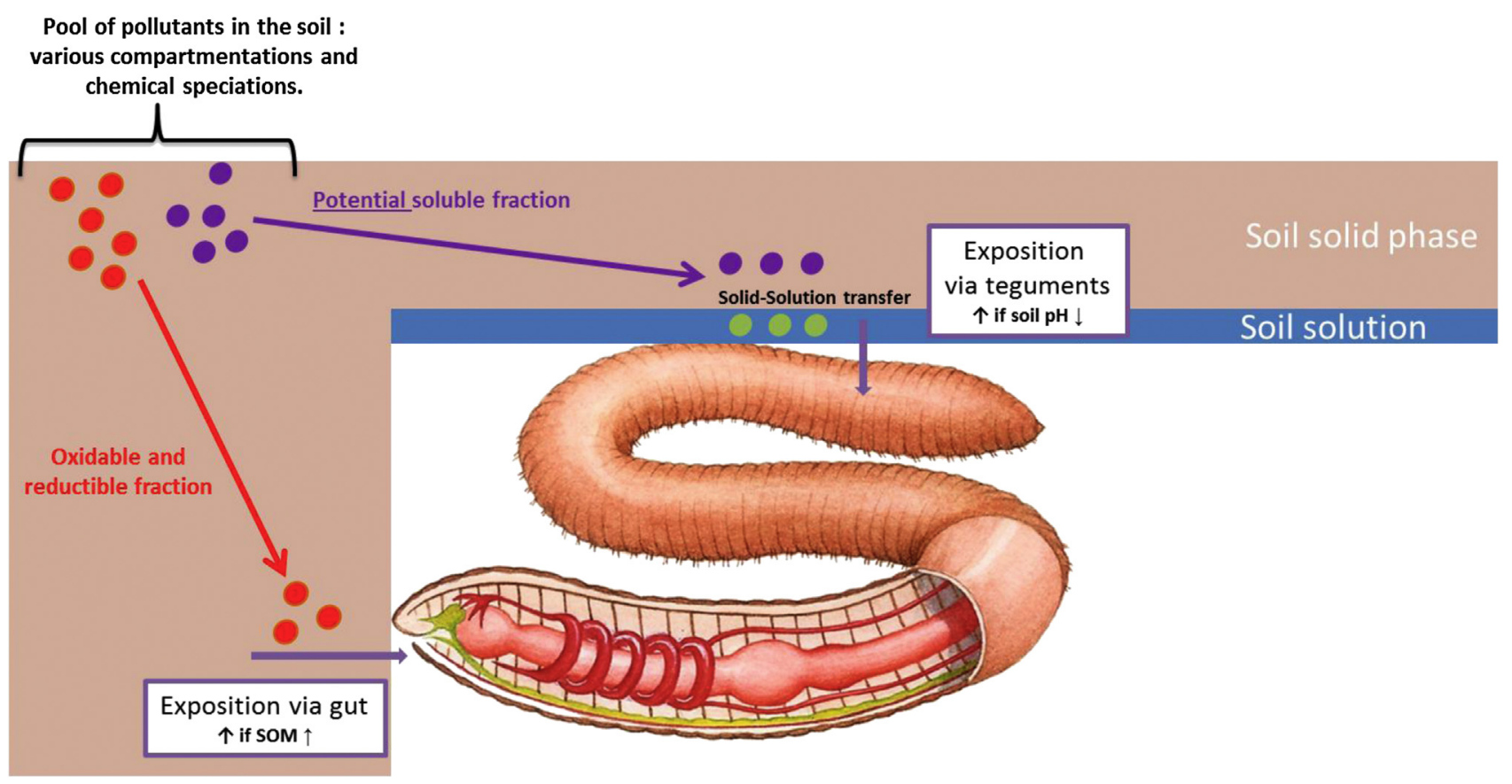

Leveque et al., 2012

Fig. 5. Heavy metal exposure pathways in earthworms related to soil characteristics.

the species and even populations is largely recommended to gain the most insight into soil contamination and its toxicity for invertebrates.

\section{Conclusions and perspectives}

This study focused on the ecotoxicity of two soils polluted with a cocktail of metals and metalloids on two earthworm species belonging to two different ecological types (Eiseina hortensis and Lumbricus terrestris). Earthworms were exposed under laboratory conditions but with a realistic source of pollution using soil collected from a lead recycling facility. The combination of behavioural factor measurements (cast production) and earthworm ITE absorption, their bioaccumulation and localization in invertebrate tissues provided a valuable indication of pollutant bioavailability and ecotoxicity. The soil properties significantly affected the impact of soil ecotoxicity and ITE uptake by earthworms, as well as their bioturbation activities in the soil.

Studies examining uptake pathways and toxicity mechanisms are still in progress on various metals and the effect of ITE on metabolic enzymes or gene expression which could be highly sensitive markers, should be investigated further. The role of earthworms in the fate of ITE in the environment (phytoavailability and human bioaccessibility) associated with their burrowing activities should also be investigated in further studies.

\section{Acknowledgements}

We gratefully acknowledge INSU-EC2CO program, ADEME, the French Agency of the Environment and Energy as well as the STCM Chemical Metal Treatment Company for their technical help in experimental set-up and for their financial support. The authors also thank Perrine Chaurand and Daniel Borschneck for their technical advices with the $\mu \mathrm{XRF}$ experiment, as well as the ECCOREV federation.

\section{References}

Andre, J., King, R.A., Stürzenbaum, S.R., Kille, P., Hodson, M.E., Morgan, A.J., 2010a. Molecular genetic differentiation in earthworms inhabiting a heterogeneous Pb-polluted landscape. Environmental Pollution 158, 883-890.

Andre, J., Stürzenbaum, S.R., Kille, P., Morgan, A.J., Hodson, M.E., 2010b. Metal bioaccumulation and cellular fractionation in an epigeic earthworm (Lumbricus rubellus): the interactive influences of population exposure histories, sitespecific geochemistry and mitochondrial genotype. Soil Biology and Biochemistry $42,1566-1573$.

Bradham, K.D., Dayton, E.A., Basta, N.T., Schroder, J., Payton, M., Lanno, R.P., 2006 Effect of soil properties on lead bioavailability and toxicity to earthworms. Environmental Toxicology and Chemistry 25 (3), 769-775.

Capowiez, Y., Dittbrenner, N., Rault, M., Triebskorn, R., Hedde, M., Mazzia, C., 2010 Earthworm cast production as a new behavioural biomarker for toxicity testing. Environmental Pollution 158 (2), 388-393.

Cecchi, M., Dumat, C., Alric, A., Felix-Faure, B., Pradere, P., Guiresse, M., 2008. Multimetal contamination of a calcic cambisol by fallout from a lead-recycling plant. Geoderma 144 (1-2), 287-298.

Cœurdassier, M., Vaufleury, A.G., Lovy, C., Badot, P.M., 2002. Is the cadmium uptake from soil important in bioaccumulation and toxic effects for snails? Ecotoxicology and Environmental Safety 53 (3), 425-431.

Davies, N.A., Hodson, M.E., Black, S., 2003. The influence of time on lead toxicity and bioaccumulation determined by the OECD earthworm toxicity test. Environmental Pollution 121 (1), 55-61.

Díez-Ortiz, M., Giska, I., Groot, M., Borgman, E.M., Van Gestel, C.A.M., 2010. Influence of soil properties on molybdenum uptake and elimination kinetics in the earthworm Eisenia andrei. Chemosphere 80 (9), 1036-1043.

Dittbrenner, N., Moser, I., Triebskorn, R., Capowiez, Y., 2011. Assessment of short and long-term effects of imidacloprid on the burrowing behaviour of two earthworm species by using 2D and 3D post-exposure techniques. Chemosphere 84 (10), 1349-1355.

Dumat, C., Quenea, K., Bermond, A., Toinen, S., Benedetti, M.F., 2006. Study of the trace metal ion influence on the turnover of soil organic matter in cultivated contaminated soils. Environmental Pollution 142 (3), 521-529.

Ernst, G., Zimmermann, S., Christie, P., Frey, B., 2008. Mercury, cadmium and lead concentrations in different ecophysiological groups of earthworms in forest soils. Environmental Pollution 156 (3), 1304-1313.

Foucault, Y., Durand, M.J., Tacke, K., Schreck, E., Geret, F., Leveque, T., Pradere, P., Goix, S., Dumat, C., 2013. Use of ecotoxicity test and ecoscores to improve the management of polluted soils: case of a secondary lead smelter plant. Journal of Hazardous Materials 246-247, 291-299.

Fuller-Espie, S.L., 2010. Vertebrate cytokines interleukin 12 and gamma interferon, but not interleukin 10, enhance phagocytosis in the annelid Eisenia hortensis. Journal of Invertebrate Pathology 104 (2), 119-124. 
Hagopian, T., Chandler, G., Shaw, T., 2001. Acute toxicity of sediment associated metals, individually and in a mixture, to the estuarine meiobenthic harpacticoid copepod Amphiascus tenuiremis. Marine Environmental Research 51 (3), 247-264.

Hobbelen, P.H.F., Koolhaas, J.E., van Gestel, C.A.M., 2006. Bioaccumulation of heavy metals in the earthworms Lumbricus rubellus and Aporrectodea caliginosa in relation to total and available metal concentrations in field soils. Environmental Pollution 144 (2), 639-646.

Jones, R.P., Bednar, A.J., Inouye, L.S., 2009. Subcellular compartimentalization of lead in the earthworm Eisenia fetida: relatioship to survival and reproduction. Ecotoxicology and Environmental Safety 72 (4), 1045-1052.

Kılıç, G.A., 2011. Histopathological and biochemical alterations of the earthworm (Lumbricus Terrestris) as biomarker of soil pollution along Porsuk River Basin (Turkey). Chemosphere 83, 1175-1180.

Lapied, E., Nahmani, J.Y., Moudilou, E., Chaurand, P., Labille, J., Rose, J., Exbrayat, J.M., Oughton, D.H., Joner, E.J., 2011. Ecotoxicological effects of an aged $\mathrm{TiO}_{2}$ nanocomposite measured as apoptosis in the anecic earthworm Lumbricus terrestris after exposure through water, food and soil. Environment International 37 (6), 1105-1110.

Li, X.D., Thornton, I., 2001. Chemical partitioning of heavy and major elements in soils contaminated by mining and smelting activities. Applied Geochemistry 16, 1693-1706.

Li, L.Z., Zhou, D., Wang, P., Luo, X.S., 2008. Subcellular distribution of $\mathrm{Cd}$ and $\mathrm{Pb}$ in earthworm Eisenia fetida as affected by $\mathrm{Ca}^{2+}$ ions and $\mathrm{Cd}-\mathrm{Pb}$ interaction. Ecotoxicology and Environmental Safety 71 (3), 632-637.

Lukkari, T., Haimi, J., 2005. Avoidance of $\mathrm{Cu}$ and $\mathrm{Zn}$ contaminated soil by 3 ecologically different earthworm species. Ecotoxicology and Environmental Safety 62 (1), 35-41.

Maleri, R.A., Reinecke, A.J., Reinecke, S.A., 2008. Metal uptake of two ecophysiologically different earthworms (Eisenia fetida and Aporrectodea caliginosa) exposed to ultramafic soils. Applied Soil Ecology 38 (1), 42-50.

Menzies, N.W., Donn, M.J., Kopittke, P.M., 2007. Evaluation of extractants for estimation of the phytoavailable trace metals in soils. Environmental Pollution 145 (1), 121-130.

Morgan, A.J., 1984. The Localization of Heavy Metals in the Tissues of Terrestria Macroinvertebrates by Electron Microprobe X-ray Analysis. Scanning Electron Microscopy Part IV. S.E.M. Inc., Chicago, pp. 1847-1865.

Morgan, J.E., Morgan, A.J., 1993. Seasonal changes in the tissue-metal (Cd, Zn and $\mathrm{Pb}$ ) concentrations in two ecophysiologically dissimilar earthworm species: pollution-monitoring implications. Environmental Pollution 82 (1), $1-7$.

Morgan, J.E., Morgan, A.J., 1998. The distribution and intracellular compartmentation of metals in the endogeic earthworm Aporrectodea caliginosa sampled from an unpolluted and a metal-contaminated site. Environmental Pollution 99 (2) 167-175.

Morgan, J.E., Morgan, A.J., 1999. The accumulation of metals (Cd, $\mathrm{Cu}, \mathrm{Pb}, \mathrm{Zn}$ and $\mathrm{Ca}$ ) by two ecologically contrasting earthworm species (Lumbricus rubellus and Aporrectodea caliginosa): implications for ecotoxicological testing. Applied Soil Ecology 13 (1), 9-20.

Nahmani, J., Hodson, M.E., Black, S., 2007a. Effects of metals on life cycle parameters of the earthworm Eisenia fetida exposed to field-contaminated, metal-polluted soils. Environmental Pollution 149 (1), 44-58.

Nahmani, J., Hodson, M.E., Black, S., 2007b. A review of studies performed to assess metal uptake by earthworms. Environmental Pollution 145 (2), 402-424.

Nannoni, F., Protano, G., Riccobono, F., 2011. Uptake and bioaccumulation of heavy elements by two earthworm species from a smelter contaminated area in northern Kosovo. Soil Biology and Biochemistry 43 (12), 23592367.
Owojori, O.J., Reinecke, A.J., Rozanov, A.B., 2008. Effects of salinity on partitioning, uptake and toxicity of zinc in the earthworm Eisenia fetida. Soil Biology and Biochemistry 40 (9), 2385-2393.

Owojori, O.J., Reinecke, A.J., Rozanov, A.B., 2009. Role of clay content in partitioning, uptake and toxicity of zinc in the earthworm Eisenia fetida. Ecotoxicology and Environmental Safety 72 (1), 99-107.

Pauget, B., Gimbert, F., Coeurdassier, M., Scheifler, R., de Vaufleury, A., 2011. Use of chemical methods to assess $\mathrm{Cd}$ and $\mathrm{Pb}$ bioavailability to the snail Cantareus aspersus: a first attempt taking into account soil characteristics. Journal of Hazardous Materials 192 (3), 1804-1811.

Reinecke, A.J., Reinecke, S.A., Maboeta, M.S., 2001. Cocoon production and viability as endpoints in toxicity testing of heavy metals with three earthworm species. Pedobiologia 45 (1), 61-68.

Ruiz, E., Alonso-Azcárate, J., Rodríguez, L., 2011. Lumbricus terrestris L. activity increases the availability of metals and their accumulation in maize and barley. Environmental Pollution 159 (3), 722-728.

Schreck, E., Geret, F., Gontier, L., Treilhou, M., 2008. Neurotoxic effect and metabolic responses induced by a mixture of six pesticides on the earthworm Aporrectodea caliginosa nocturna. Chemosphere 71 (10), 1832-1839.

Schreck, E., Foucault, Y., Geret, F., Pradere, P., Dumat, C., 2011. Influence of soil ageing on bioavailability and ecotoxicity of lead carried by process waste metallic ultrafine particles. Chemosphere 85 (10), 1555-1562.

Schreck, E., Foucault, Y., Sarret, G., Sobanska, S., Cécillon, L.M., Uzu, G., Dumat, C., 2012. Metal and metalloid foliar uptake by plant species exposed to atmospheric industrial fallout. Science of The Total Environment 427-428 (0), 253-262.

Sizmur, T., Hodson, M.E., 2009. Do earthworms impact metal mobility and availability in soil? A review. Environmental Pollution 157 (7), 1981-1989.

Suthar, S., Singh, S., Dhawan, S., 2008. Earthworms as bioindicator of metals (Zn, Fe, $\mathrm{Mn}, \mathrm{Cu}, \mathrm{Pb}$ and $\mathrm{Cd}$ ) in soils: Is metal bioaccumulation affected by their ecological category? Ecological Engineering 32 (2), 99-107.

Tomlin, A.D., 1992. Behaviour as a source of earthworm susceptibility to ecotoxicants. In: Greig-Smith, P.W., Becker, H., Edwards, P.J., Heimbach, F. (Eds.), Ecotoxicoly of Earthworms, Intercept, Andover, pp. 116-125.

Uzu, G., Sobanska, S., Aliouane, Y., Pradere, P., Dumat, C., 2009. Study of lead phytoavailability for atmospheric industrial micronic and sub-micronic particles in relation with lead speciation. Environmental Pollution 157 (4), 1178-1185.

van Gestel, C.A.M., Ortiz, M.D., Borgman, E., Verweij, R.A., 2011. The bioaccumulation of molybdenum in the earthworm Eisenia andrei: influence of soil properties and ageing. Chemosphere 82 (11), 1614-1619.

Vandecasteele, B., Samyn, J., Quataert, P., Muys, B., Tack, F.M.G., 2004. Earthworm biomass as additional information for risk assessment of heavy metal biomagnification: a case study for dredged sediment-derived soils and polluted floodplain soils. Environmental Pollution 129 (3), 363-375.

Vijver, M.G., Vink, C.J., van Gestel, C.A., 2003. Oral sealing using glue: a new method to distinguish between intestinal and dermal uptake of metals in earthworms. Soil Biology and Biochemistry 35 (1), 125-132.

Vorenhout, M., Van Straalen, N.M., Eijsackers, H.J.P., 2000. Assessment of the purifying function of the ecosystems. Environmental Toxicology and Chemistry 19 (9), 2161-2163.

Wròblewski, R., Roomans, G.M., Ruusa, J., Hedberg, B., 1979. Elemental analysis of histochemically defined cells in the earthworm Lumbricus terrestris. Histochemistry $61,167-176$.

Wu, B., Liu, Z., Xu, Y., Li, D., Li, M., 2012. Combined toxicity of cadmium and lead on the earthworm Eisenia fetida (Annelida, Oligochaeta). Ecotoxicology and Environmental Safety $81(0), 122-126$.

Zheng, R., Li, C., 2009. Effect of lead on survival, locomotion and sperm morphology of Asian earthworm, Pheretima guillelmi. Journal of Environmental Sciences 21, 691-695. 